\title{
¿ Research S Suare \\ Spatial analysis of confirmed Lassa fever cases in Edo State, Nigeria, 2008 - 2014
}

\section{Samuel Amifofum Owoicho ( $\nabla$ samuelowoicho52@gmail.com )}

Nigeria Field Epidemiology and Laboratory Training Program(NFELTP) https://orcid.org/0000-00018282-019X

\section{Emmanuel Awosanya}

Centre for Control and Prevention of Zoonoses, Faculty of Veterinary Medicine,University of Ibadan,Ibadan,Nigeria

\section{Dorcas Fadugba}

Centre for Control and Prevention of Zoonoses, Faculty of Veterinary Medicine, University of Ibadan,Ibadan,Nigeria

\section{Muhammad Shakir Balogun}

Nigeria Field Epidemiology and Laboratory Training Program

\section{Patrick Nguku}

Nigeria Field Epidemiology and Laboratory Training Program

\section{Simon Ajisegiri}

Nigeria Field Epidemiology and Laboratory Training Program

\section{Odigie Eugene}

Center for Control and Prevention of Zoonoses,Faculty of Veterinary Medicine,University of Ibadan,Ibadan,Nigeria

\section{Babasola Olugasa}

Centre for Control and Prevention of Zoonoses,Faculty of Veterinary Medicine,University of Ibadan,Ibadan,Nigeria

\section{Research article}

Keywords: Multi-criteria analysis, Lassa fever, environmental variables, Nigeria

Posted Date: November 20th, 2019

DOI: https://doi.org/10.21203/rs.2.13776/v2

License: (9) This work is licensed under a Creative Commons Attribution 4.0 International License. Read Full License 


\section{Abstract}

Background: Lassa fever (LF) is endemic and poses public health threats in Edo State. Identification of primary clusters will help prioritize public health interventions in the state. We investigated retrospective cases of LF to identify primary cluster of the disease for household exposure management. Method: We reviewed retrospective data $(n=1400)$ of LF case-patients at a referral hospital in Edo State from 2008 to 2014 based on World Health Organization case definition for LF. We determined primary cluster of confirmed cases on Bernoulli model and evaluated environmental factors in the primary cluster: presence of rodent deterrents, proximity of households at $2 \mathrm{~km}$ radius to rice farm, rice post-harvest storage facility, refuse dump, forest, hospital and main road using Multi-criteria analysis at $p<0.05$. Results: Of the reviewed cases, 171 (12.2\%) were confirmed case-patients. The median age of confirmed case-patients was 30 years (Q1:16.0 and Q3: 43.5). Of the confirmed case-patients, 101 (59.1\%) were male. A primary spatial cluster ( $4.45 \mathrm{~km}$ radius; geographic centre at $6.717900 \mathrm{oN}, 6.243500 \mathrm{oE})$ was identified in Esan West LGA. Associated environmental factors included presence of rodent deterrents $(p<0.001)$, proximities of households to refuse dump $(p<0.001)$, rice post-harvest storage facility $(p=0.01)$ and rice farm $(p=0.03)$. Conclusion: Esan West LGA was identified as a primary cluster for Lassa fever. Presence of rodent deterrents, household proximity to refuse dump sites, rice storage facilities and rice farms were associated environmental factors. We recommend improved rice post-harvest storage and use of rodent deterrents in Edo State, Nigeria. Key words: Multi-criteria analysis, Lassa fever, environmental variables, Nigeria.

\section{Background}

Lassa fever (LF) is a viral haemorrhagic zoonotic disease caused by an arenavirus. Humans get infected with the virus primarily through ingestion of food or food substances contaminated with the excreta of Mastomys natalensis rodent (commonly known as the Multimammate rat), which is the natural reservoir for the virus. Human to human transmission is also possible through contact with secretions and excretions of infected persons(1). LF is predominant in West Africa including Sierra Leone, Liberia and Nigeria(2). It affects 100,000 to 300,000 people every year in this region(3). There have been several LF outbreaks in various parts of Nigeria and the largest outbreak ever reported was in 2018 which shows an increasing trend in the number of cases and deaths(4). In 2018, a total of 3016 suspected LF cases were reported from 22 states. Of these cases, 559 were confirmed positive, 17 probable and 2440 negative. The case fatality rate among confirmed cases was $25.6 \%$ and $100 \%$ among probable cases. All the affected 22 states had at least one confirmed case spreading through 90 Local Government Areas (LGAs). Three of the 22 affected states constituted $83.0 \%$ of the confirmed cases: Edo (46\%), Ondo (24\%) and Ebonyi (13\%) states (4). Edo State is one of the states in Nigeria with high burden of LF cases with occurrence all through the year. The first outbreak of LF in Edo State occurred in Esan West LGA in 1989 (3)(5). Identification of primary spatial clusters have contributed immensely to understanding disease risk behavior as well as help guide and inform prioritization of public health intervention strategies(6). Studies have indicated that habitat suitability such as agricultural intensification associated with post-harvest 
grain, storage density on residential areas could significantly influence Mastomys breeding and transmission of the Lassa virus to humans (7)(1). Geographic information system (GIS) and spatial models have been used to gain better understanding about the risk distribution of LF along West Africa sub-region (8). This study, therefore, aimed at identifying primary spatial cluster for confirmed LF cases in Edo State, an endemic LF state, and its' associated environmental factors in the primary cluster

\section{Methods}

\section{Study Design}

A retrospective review of data on LF cases presented at the Institute for Lassa fever Research and Control, Irrua, Edo State between 2008 and 2014.

\section{Study Location}

Edo State is one of the states in the South - south geo-political zone of Nigeria; lying on $05^{\prime} 44 \mathrm{~N}$ and 07'34 N latitudes, 05' $4 \mathrm{E}$ and 06'45 E longitudes (Figure 1), and mostly tropical rain forest.

Administratively, it has 3 senatorial zones (Edo North, Edo Central and Edo South), 18 LGAs and 192 wards. The 2018 projected human population for Edo State from the 2006 national population census was $4,600,000$. Agriculture is the main occupation of the people (FGN 2019). Edo State has 472 health facilities with 55 private health facilities and the Institute for Lassa fever Research and Control situated at Irrua in Esan Central LGA.

\section{Case Definition}

LF case was established based on the World Health Organization (WHO) definition, 2004.

\section{Suspected case}

A suspected case was a person with acute illness of $<3$ weeks duration, with temperature of $38^{\circ} \mathrm{C}$ and above, showing no response to effective antimalarial treatment after the first dose and no response to chloramphenicol treatment afters 48 hours.

\section{Probable case}

A probable case was a person with clinical illness, not laboratory confirmed and was not epidemiologically linked to a confirmed case but with appropriate exposure history.

\section{Confirmed case of LF}

A confirmed case of LF was a person that was confirmed in the Laboratory, or that met the clinical illness case defined by the WHO and was not laboratory confirmed case but epidemiological linked to a confirmed case. 


\section{Controls}

Suspected cases that were tested negative in corresponding locations in which confirmed cases were located.

\section{Data Collection}

All cases obtained from the retrospective record were reviewed, a total of 1,400 suspected, probable and confirmed cases. Data on the age, sex, house location and laboratory status were extracted for all laboratory confirmed cases.

We visited house locations of confirmed LF case-patients and controls and geographic coordinates of their house locations were obtained using the handheld geographic positioning system (GPS). Where the house locations of case-patients could not be reached and majority of locations of controls, geographic coordinates were captured using Google Earth Pro images for geo-positioning. Data on age, sex, number of cases and geo-coordinates in each LGA were line listed on Microsoft Excel spreadsheet. After determining primary spatial cluster for LF cases, an observational check-list was used to assess environmental risk factors of case-patients' households in the primary spatial cluster. We considered environmental risk factors that could favor the breeding and access of mastomys rat such as proximity of household to rice farms, rice post-harvest storage facilities, refuse dump sites and presence of rodent deterrents [7]; and other environmental factors such as proximity of households to forest, main road and hospital facilities. By presence of rodent deterrents: we observed the houses of LF case-patients for

absence of cracks and crevices in the windows, doors and walls. All proximities were considered at $2 \mathrm{~km}$ radius of the house locations of confirmed LF case-patients to any of the environmental factors considered.

\section{Data Analysis}

Kulldorff Sat Scan software was used to estimate primary clustered location. Associated environmental factors of LF cases in the primary cluster were determined using spatial regression with Geoda software. Eight spatial features were individually tested as predictors of LF cases in the primary clustered area through multi-criterial analysis (MCA)(1). Spatially lag independent variables were grouped into two subsets to reveal the effects of groups 1 and 2 characteristics separately. Group one examined the effects of environmental variables related to residential areas at proximity of $2 \mathrm{~km}$, while group 2 examined the rodent dynamics related variables. Variables were subjected to regression equation: (8) where:is an $\mathrm{x}$ by 1 Lassa fever case, is referred to as a spatial weights matrix. For each location in the system, it specifies which of the other locations in the system affect the value at that location. This is necessary, since in contrast to the unambiguous notion of a "shift" along the time axis (such as in an autoregressive model), there is no corresponding concept in the spatial domain, especially when observations are located irregularly in space. Instead of the notion of shift, a spatial lag operator is used, which is a weighted average of random variables at "neighboring" locations, in conclusion, is a spatial weighted matrix of neighboring locations of the regression model, is the scalar spatial coefficient, is an $\mathrm{N}$ 
by 1 weighted matrix of Lassa fever cases, $\mathrm{X}$ is an $\mathrm{N}$ by $\mathrm{k}$ matrix of explanatory variables ( $\mathrm{X} 1$ forest proximity, X2 Household proximity to main road, X3 Hospital proximity and X4 is human population density). $\mathrm{B}$ is a $\mathrm{k}$ by 1 vector of parameters, is an $\mathrm{N}$ by 1 vector of random error terms. Data were analyzed at $p<0.05$ (as shown in table 3 line 1 to 30 ) (9)

\section{Results}

Of the 1,400 case records for LF reviewed; 171 (12.2\%) were laboratory confirmed. Of the 171 confirmed cases, 101 (59.1\%) were male. Figure 2 showed the spatial distribution of cases by sex. The median age of the confirmed case-patients was 30 years (IOQ: 27.5). Most (32.8\%) affected age group was within 25 - 34 years and most (43.2 \%) of the confirmed case-patients were from Esan West LGA (Table 1). A primary spatial cluster $\left(4.45 \mathrm{~km}\right.$ radius; geographic centre at $\left.6.717900^{\circ} \mathrm{N}, 6.243500^{\circ} \mathrm{E}\right)$ for $\mathrm{LF}$ cases was identified in Esan West LGA (Figure 3) and was significant at $p=0.04$ (Table 2). Environmental variables related to rodent dynamics that significantly characterized house locations of LF case-patients were presence of rodent deterrents $(p<0.001)$, proximities of households to refuse dump $(p<0.001)$, rice postharvest storage facility $(p=0.01)$ and rice farm $(p=0.03)$. However, other environmental variables such as proximity of households to forest, main road and hospital facilities were not significantly associated with house locations of LF case-patients (Table 3). Figures 4 and 5 showed the aerial photographs of environmental variables in relation to house location of a LF confirm case-patient; and in relation to house locations in the primary cluster of Lassa fever cases in the study area.

Table 1: Distribution of confirmed Lassa fever cases by age, gender and LGAs in Edo State, $2008-2014$ 


\begin{tabular}{ll}
\hline Age group & Cases $\mathbf{n}=\mathbf{1 7 1}(\%)$ \\
\hline $0-14$ & $38(22.2)$ \\
$15-24$ & $24(14.0)$ \\
$25-34$ & $56(32.8)$ \\
$35-44$ & $21(12.3)$ \\
$\geq 45$ & $32(18.7)$ \\
& \\
\hline Sex & Cases $\mathbf{n = 1 7 1 ( \% )}$ \\
\hline Male & $101(59.1)$ \\
Female & $70(40.9)$
\end{tabular}

\begin{tabular}{lll}
\hline Senatorial Districts & LGAs & Cases n=171(\%) \\
\hline Edo Central & & \\
& Esan Central & $32(18.7)$ \\
& Esan North East & $36(21.0)$ \\
& Esan South East & $3(1.8)$ \\
& Esan West & $74(43.2)$ \\
& Igueben & $5(2.9)$ \\
Edo South & & \\
& Oredo & $3(1.8)$ \\
& Orhionmwon & $0(0.0)$ \\
& Ovia North - East & $3(1.8)$ \\
& Ikpoba Okha & $2(1.2)$ \\
& Uhumwonde & $0(0.0)$ \\
& Ovia South - West & $0(0.0)$ \\
& Egor & $1(0.5)$ \\
& & \\
& Etsako East & $5(2.9)$ \\
& Etsako West & $3(1.8)$ \\
& Owan West & $2(1.2)$ \\
& Etsako Central & $0(0.0)$ \\
& Akoko Edo & $0(0.0)$ \\
& Owan East & $2(1.2)$ \\
\hline
\end{tabular}

Table 2: Spatial cluster of confirmed Lassa fever cases in Edo State, 2008 - 2014 


\begin{tabular}{llllllll}
\hline Type & $\begin{array}{l}\text { Local Government } \\
\text { Areas }\end{array}$ & $\begin{array}{l}\text { Obs. } \\
\text { Cases }\end{array}$ & $\begin{array}{l}\text { Expec. } \\
\text { cases }\end{array}$ & $\begin{array}{l}\text { Control } \\
\text { Relative }\end{array}$ & $\begin{array}{l}\text { P- } \\
\text { risk }\end{array}$ & $\begin{array}{l}\text { LLR } \\
\text { value }\end{array}$ \\
\hline $\begin{array}{l}\text { Primary } \\
\text { cluster }\end{array}$ & Esan West & 49 & 8.03 & 15 & 3.12 & $0.04^{*}$ & 4.23 \\
$\begin{array}{l}\text { Secondary } \\
\mathbf{1}\end{array}$ & Etsako East/Etsako & 9 & 3.18 & 6 & 1.20 & 0.22 & 2.03 \\
$\begin{array}{l}\text { Secondary } \\
\mathbf{2}\end{array}$ & Oredo/Okpoba- & 3 & 0.27 & 1 & 0.13 & 0.65 & 1.12 \\
\hline
\end{tabular}

${ }_{*}^{*}=P$-value $\leq 0.05, L L R=\log$ Likelihood Ratio

Table 3: Multi-factorial characteristics of confirmed LF primary cluster in Esan west Local Government Area, Edo State, 2008 - 2014

\begin{tabular}{llll}
\hline Group: Variables & B & SE & P-value \\
\hline Group 1: House Location & & & \\
Forest Proximity & -0.03 & 0.03 & 0.33 \\
Main road Proximity & -0.01 & 0.01 & 0.16 \\
Hospital Proximity & -0.04 & 0.01 & 0.20 \\
Population Density & -0.39 & 4.43 & 0.62 \\
Group 2: Rodent dynamics & & & \\
Rice farm proximity & -0.53 & 0.11 & $0.03^{*}$ \\
Rice post-harvest storage & 1.31 & 0.32 & $0.01 *$ \\
Refuse dump proximity & -0.21 & 0.77 & $\square 0.001^{*}$ \\
Rodents deterrent presence & -1.57 & 0.82 & $\square 0.001^{*}$ \\
\hline
\end{tabular}

$$
S E=\text { Standard Error } ; B=\text { Beta coefficient; } * \text { Significant at } p<0.05
$$

\section{Discussion}

A significant primary spatial cluster/ hotspot for LF cases was identified in Esan West LGA, Edo State Nigeria in this study, while Secondary 1 cluster comprises of Etsako west and Secondary 2 clusters were 
found in Oredo, Ikpoba - okha and Egor Local Government Areas. This is similar to the findings of Ike and Asogun (2016) who reported LF hotspot in Ekpoma town in Esan West LGA in the same study location. This is an indication of the endemicity of LF virus in Esan West LGA. The identification of hotspot in Esan West LGA finds application in planning and strategic intervention for the effective prevention and control of LF in Edo State(5). It could also suggest the source of rodent-human contact interface as reported by Karan (2019) who highlighted four hotspots for LF among Mastomys natalensis population in Guinea and found a major hotspot around marketplace suggesting the source of Mastomys natalensis to human households in the study location.

One of the environmental risk variables related to rodent dynamics that significantly characterized house locations of LF case-patients was proximity of rice post-harvest storage facility. Post-harvest storage facilities for grains have been found to attract rodents especially Mastomys natalensis (1). Similarly, Olugasa (2014) found significant risk association between rice storage post-harvest and LF outbreaks on a rubber plantation in Liberia. Grains such as rice serve as food to rodents and will encourage their presence in the surrounding of the storage facility especially where the hygiene practice is poor and no rodent control is in place. However, rodent-human interface is essential for disease transmission via ingestion of food or food substances contaminated with the excreta of LF infected Mastomys natalensis rodents. During pre-harvest season when the source of food to the rodents are either absent or inadequate, they migrate to households in the proximity in search of food, thus creating the rodenthuman interface needed for possible disease transmission. In a study in Sierra Leone, more rodents were trapped within household than the environment and most of the trapped rodents were predominantly Mastomys natalensis(1).

Our model also revealed that the presence of rodent deterrents in households was found to be a significant protective factor associated with LF case-patients. Absence of cracks in walls, spaces either through the windows or doors, presence of wire mesh have been reported to be effective in breaking the rodent-human interface needed to provide disease transmission pathways (24). (25) found the presence of rodent burrows and external hygiene around houses to be directly associated with a history of LF in the household in Sierra Leone. Though, a study in Nigeria found no significant difference in households of LF positive cases and controls with respect to housing quality (26). Other significant protective environmental variables in our model included rice farms and refuse dumps in proximities of $2 \mathrm{~km}$ radius to the house locations of confirmed LF case-patients. Rice farms and refuse dumps sites have been reported to harbour rodents especially Mastomys natalensis because of the availability of food at these sites (27) (28) (29). The continuous presence of food to rodents at these sites and at distance of $2 \mathrm{~km}$ possibly served as possible means for rodent visiting human dwellings thus preventing the human-rodent interface needed for disease transmission in the human space. The preponderance of Mastomys natalensis in houses in rural settlements in East African countries (24) and Rattus rattus in some urban areas in sub-Saharan Africa. However, Karan (2019) reported a preponderance of Mastomys natalensis in residential areas in Urban areas in Guinea. The distance of the food sources - rice farms and refuse dumps to human dwellings could explain the reduction in LF cases in those households despite their preponderances. 
Other environmental variables such as proximity of households to forest, main road and hospital facilities were not significantly associated with house locations of LF case-patients. This is similar to the findings of Olugasa (2014) in Liberia. Leach (2017) reported absence of capture of Mastomys natalensis in forests, tree crops and mining areas in Sierra Leone. Rodent population size is limited by several factors which include food quantity and quality, presence of nesting sites, control activities etc. (34).

Esan West LGA was identified as a primary cluster for Lassa fever. Environmental factors related to rodent dynamics were associated with LF hotspot in Edo State. Presence of post-harvest rice storage was a risk factor associated with households of case-patients in the hotspot. Presence of rodent deterrents, household proximity to rice farms and refuse dump sites at $2 \mathrm{~km}$ were protective environmental factors associated with households of case-patients in the hotspot. We recommend use of rodent proof rice postharvest storage facility and use of rodent deterrents in Edo State, Nigeria.

\section{Conclusion}

- Esan West LGA was identified as a primary cluster for Lassa fever cases and hence the hotspot of the disease in Edo State

- Household proximity to refuse dump sites, rice storage facilities and rice farms were associated environmental factors to Lassa fever cases across the clusters

\section{Abbreviations}

LF - Lassa Fever, $\mathrm{n}$ - Number, Km - Kilometer, P- Prevalence, <- Less than, \% - Percentage, WHO - World Health Organization, GPS - Geographic Positioning System, MCA - Multi-criterial analysis, * - Pvalue $\leq 0.05$, LLR - Log Likelihood Ratio, SE - Standard Error; B - Beta coefficient.

\section{Declarations}

\section{- Ethics approval and consent to participate}

Research and Ethics Committee of Edo State Ministry of Health

Reference Number: HM.1208/188

\section{- Consent for Publication}

Stated in the Ethical approval letter above.

\section{- Availability of data and materials}

The data that supported the findings of this study were available from Edo State Ministry of Health but restrictions applied to the availability of these data, which were used under license for the current study, 
and so are not publicly available. Data were however available upon reasonable request and with permission of Edo State Ministry of Health and instruction not to disclose it in public.

\section{- Competing interests}

The authors declare that they have no competing interests.

\section{- Funding}

No funding for this research work

\section{- Authors' contributions}

EA Supervised this work, FD contributed in data collection, MSB mentored me for this work, SA Mentored me, PN mentored me, EO Mentored me in data analysis, BO Mentored me in data analysis and ethical approval and consent for publication from Edo State Ministry of Health.

\section{- Acknowledgements}

I acknowledge the following persons in ensuring the success of this publication: Dr Icomiare Adebudo, Dr Irowa Abiodun, Mrs Oboro Kehinde, Dr Ogunro Bamidele and Dr Chukwuma Umeokonkwo

\section{References}

1. Olugasa BO, Dogba JB, Ogunro B, Odigie EA, Nykoi J, Ojo JF, et al. The rubber plantation environment and Lassa fever epidemics in Liberia, 2008-2012: a spatial regression. Spat Spatiotemporal Epidemiol [Internet]. 2014 Oct [cited 2019 May 19];11:163-74. Available from: http://www.ncbi.nlm.nih.gov/pubmed/25457605

2. Bond N, Schieffelin JS, Moses LM, Bennett AJ, Bausch DG. A historical look at the first reported cases of Lassa fever: IgG antibodies 40 years after acute infection. Am J Trop Med Hyg [Internet]. 2013 Feb [cited 2019 Apr 10];88(2):241-4. Available from: http://www.ncbi.nlm.nih.gov/pubmed/23390223

3. Asogun DA, Adomeh DI, Ehimuan J, Odia I, Hass M, Gabriel M, et al. Molecular Diagnostics for Lassa Fever at Irrua Specialist Teaching Hospital, Nigeria: Lessons Learnt from Two Years of Laboratory Operation. Bausch DG, editor. PLoS Negl Trop Dis [Internet]. 2012 Sep 27 [cited 2019 May 18];6(9):e1839. Available from: http://dx.plos.org/10.1371/journal.pntd.0001839

4. Ilori EA, Frank C, Dan-Nwafor CC, Ipadeola O, Krings A, Ukponu W, et al. Increase in Lassa Fever Cases in Nigeria, January-March 2018. Emerg Infect Dis [Internet]. 2019 May [cited 2019 May 18];25(5):1026-7. Available from: http://wwwnc.cdc.gov/eid/article/25/5/18-1247_article.htm

5. Tobin E, Asogun D, Akpede N, Adomeh D, Odia I, Gunther S. Lassa fever in Nigeria: Insights into seroprevalence and risk factors in rural Edo State: A pilot study. J Med Trop [Internet]. 2015 [cited 2019 May 3];17(2):51. Available from: http://www.jmedtropics.org/text.asp?2015/17/2/51/162258 
6. Moise IK, Kalipeni E. Applications of geospatial analysis to surveillance data: a spatial examination of HIV/AIDS prevalence in Zambia. GeoJournal [Internet]. 2012 Aug 4 [cited 2019 May 1];77(4):52540. Available from: http://link.springer.com/10.1007/s10708-010-9349-7

7. Olugasa B, Dogba J. Mapping of Lassa fever cases in post-conflict Liberia, 2008-2012: A descriptive and categorical analysis of age, gender and seasonal pattern. Ann Afr Med [Internet]. 2015 [cited 2019 May 18];14(2):120. Available from: http://www.ncbi.nlm.nih.gov/pubmed/25693822

8. Anselin L, Syabri I, Kho Y. GeoDa: An Introduction to Spatial Data Analysis. Geogr Anal [Internet]. 2006 Jan 1 [cited 2019 May 19];38(1):5-22. Available from: http://doi.wiley.com/10.1111/j.00167363.2005.00671.x

9. Anselin L. Spatial Econometrics [Internet]. 2001 [cited 2019 May 20]. Available from: http://web.pdx.edu/ crkl/WISE/SEAUG/papers/anselin01_CTE14.pdf

10. Olugasa BO. The geo-spatial information infrastructure at the Centre for Control and Prevention of Zoonoses, University of Ibadan, Nigeria: an emerging sustainable One-Health pavilion. Afr J Med Med Sci [Internet]. 2014 Dec [cited 2019 May 19];43 Suppl:65-78. Available from: http://www.ncbi.nlm.nih.gov/pubmed/26949783

11. WHO | Lassa Fever - Nigeria. WHO [Internet]. 2017 [cited 2019 May 18]; Available from: https://www.who.int/csr/don/28-june-2017-lassa-fever-nigeria/en/

12. Asogun DA, Adomeh DI, Ehimuan J, Odia I, Hass M, Gabriel M, et al. Molecular Diagnostics for Lassa Fever at Irrua Specialist Teaching Hospital, Nigeria: Lessons Learnt from Two Years of Laboratory Operation. Bausch DG, editor. PLoS Negl Trop Dis [Internet]. 2012 Sep 27 [cited 2019 May 18];6(9):e1839. Available from: http://dx.plos.org/10.1371/journal.pntd.0001839

13. US Centers for Disease Control and Prevention. Lassa Fever I CDC [Internet]. CDC. 2015 [cited 2019 May 20]. Available from: https://www.cdc.gov/vhf/lassa/index.html

14. 2018 Lassa Fever Outbreak in Nigeria: NCDC Situation Report \#45 - 11 November 2018 - Nigeria | ReliefWeb [Internet]. [cited 2019 Apr 26]. Available from: https://reliefweb.int/report/nigeria/2018lassa-fever-outbreak-nigeria-ncdc-situation-report-45-11-november-2018

15. Tobin E, Asogun D, Akpede N, Adomeh D, Odia I, Gunther S. Lassa fever in Nigeria: Insights into seroprevalence and risk factors in rural Edo State: A pilot study. J Med Trop [Internet]. 2015 [cited 2019 May 3];17(2):51. Available from: http://www.jmedtropics.org/text.asp?2015/17/2/51/162258

16. Moise IK, Kalipeni E. Applications of geospatial analysis to surveillance data: a spatial examination of HIV/AIDS prevalence in Zambia. GeoJournal [Internet]. 2012 Aug 4 [cited 2019 May 1];77(4):52540. Available from: http://link.springer.com/10.1007/s10708-010-9349-7

17. Gao S, Oldfield E, Mioc D, Yi X, Anton F. Geospatial web services and applications for infectious disease surveillance. 2009 [cited 2019 May 20]; Available from: www.witpress.com,

18. Olugasa B, Dogba J. Mapping of Lassa fever cases in post-conflict Liberia, 2008-2012: A descriptive and categorical analysis of age, gender and seasonal pattern. Ann Afr Med [Internet]. 2015 [cited 2019 May 18];14(2):120. Available from: http://www.ncbi.nlm.nih.gov/pubmed/25693822 
19. Olugasa BO, Dogba JB, Ogunro B, Odigie EA, Nykoi J, Ojo JF, et al. The rubber plantation environment and Lassa fever epidemics in Liberia, 2008-2012: a spatial regression. Spat Spatiotemporal Epidemiol [Internet]. 2014 Oct [cited 2019 May 19];11:163-74. Available from: http://www.ncbi.nlm.nih.gov/pubmed/25457605

20. Anselin L, Syabri I, Kho Y. GeoDa: An Introduction to Spatial Data Analysis. Geogr Anal [Internet]. 2006 Jan 1 [cited 2019 May 19];38(1):5-22. Available from: http://doi.wiley.com/10.1111/j.00167363.2005.00671.x

21. Anselin L. Spatial Econometrics [Internet]. 2001 [cited 2019 May 20]. Available from: http://web.pdx.edu/ crkl/WISE/SEAUG/papers/anselin01_CTE14.pdf

22. Ike, C.G. and Asogun, D., 2016. Detection of clusters and geographical hotspot for Lassa fever in Edo Central Senatorial district of Nigeria: A step into a nation-wide mapping of Lassa fever. International Journal of Infectious Diseases, 45, p.227.

23. Fichet-Calvet E, Rogers DJ (2009) Risk Maps of Lassa Fever in West Africa. PLoS Negl Trop Dis 3(3): e388. https://doi.org/10.1371/journal.pntd.0000388

24. Saez, A.M., Haidara, M.C., Camara, A., Kourouma, F., Sage, M., Magassouba, N.F. and Fichet- Calvet, E., 2018. Rodent control to fight Lassa fever: Evaluation and lessons learned from a 4-year study in Upper Guinea. PLoS neglected tropical diseases, 12(11), p.e0006829.

25. Bonner PC, Schmidt WP, Belmain SR, Oshin B, Baglole D, Borchert M, 2007. Poor housing quality increases risk of rodent infestation and Lassa fever in refugee camps of Sierra Leone. Am J Trop Med Hyg 77: 169-175.

26. Ochei O, Abjejegah C, Okoh EC, Abah SO, 2014. Housing factors and transmission of Lassa fever in a rural area of south Nigeria. General Health and Medical Sciences 1: 15-20.

27. Bonwitt, J., Sáez, A.M., Lamin, J., Ansumana, R., Dawson, M., Buanie, J., Lamin, J., Sondufu, D., Borchert, M., Sahr, F. and Fichet-Calvet, E., 2017. At home with Mastomys and Rattus: human-rodent interactions and potential for primary transmission of Lassa virus in domestic spaces. The American journal of tropical medicine and hygiene, 96(4), pp.935-943.

28. Karan, L.S., Makenov, M.T., Korneev, M.G., Sacko, N., Boumbaly, S., Bayandin, R.B., Gladysheva, A.V., Kourouma, K., Toure, A.H., Kartashov, M. and Shipovalov, A.V., 2019. Lassa Virus in the Host Rodent Mastomys Natalensis within Urban Areas of N'zerekore, Guinea. BioRxiv, p.616466.

29. Belmain, S.R., Htwe, N.M., Kamal, N.Q. and Singleton, G.R., 2015. Estimating rodent losses to stored rice as a means to assess efficacy of rodent management. Wildlife Research, 42(2), pp.132-142.

30. Olugasa, B.O., Dogba, J.B., Ogunro, B., Odigie, E.A., Nykoi, J., Ojo, J.F., Taiwo, O., Kamara, A., Mulbah, C.K. and Fasunla, A.J., 2014. The rubber plantation environment and Lassa fever epidemics in Liberia, 2008-2012: A spatial regression. Spatial and spatio-temporal epidemiology, 11, pp.163-174.

31. Makundi, R.S., Massawe, A.W. and Mulungu, L.S., 2006. Ecological considerations for management of rodent pests in Tanzania.

32. Leach, M., Bett, B., Said, M., Bukachi, S., Sang, R., Anderson, N., Machila, N., Kuleszo, J., Schaten, K., Dzingirai, V. and Mangwanya, L., 2017. Local disease-ecosystem-livelihood dynamics: reflections 
from comparative case studies in Africa. Philosophical Transactions of the Royal Society B: Biological Sciences, 372(1725), p.20160163.

33. Awadall, H.I., 2013. Health effect of slums: A consequence of urbanization. Scholarly J Med, 3(1), pp.7-14.

34. Massawe, A. W., Leirs, H., Rwamugira, W. P. and Makundi, R. H. 2003. Effect of land preparation methods on spatial distribution of rodents in crop fields. In: G. R. Singleton, A. Hinds, C. J. Krebs \& D. M. Spratt (Eds)., Rats, Mice and People: Rodent Biology and Management. Australian Cantre for International Agricultural Research, Canberra, pp 229-232.

\section{Figures}

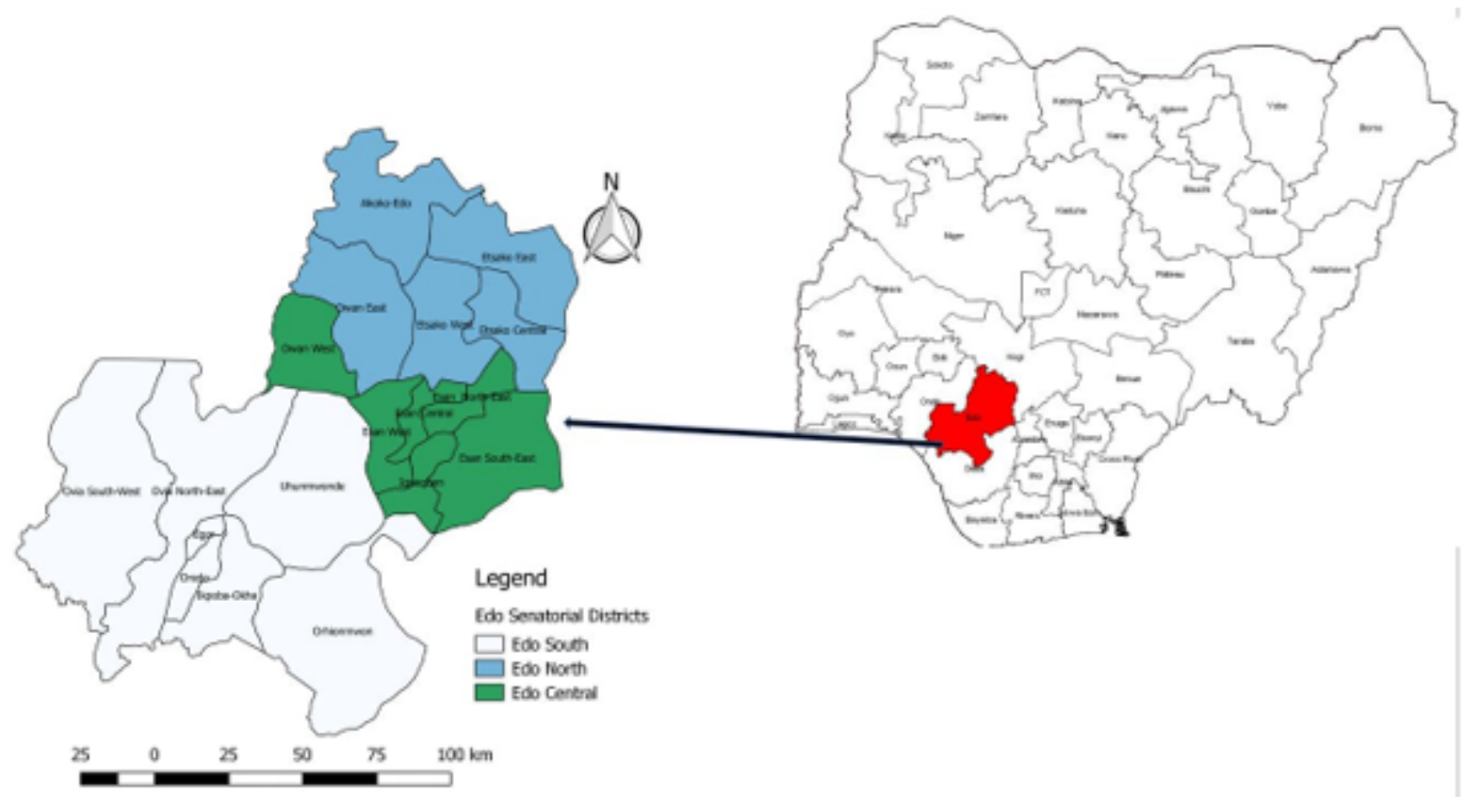

Figure 1

Map of Nigeria Showing the Location of Edo State 


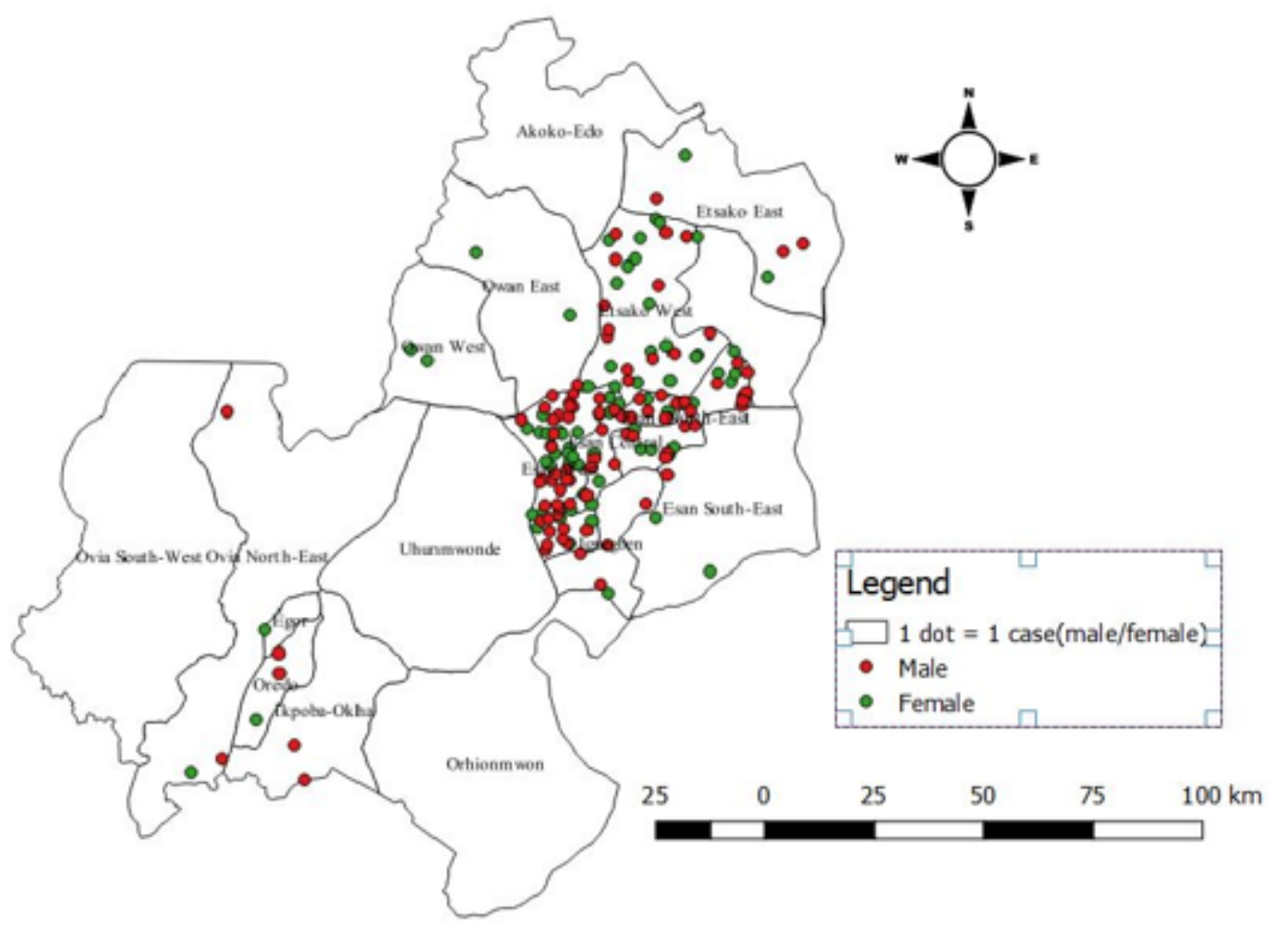

Figure 2

Dot map of confirmed Lassa fever cases by sex distribution in affected Local Government Areas in Edo State, 2008 - 2014

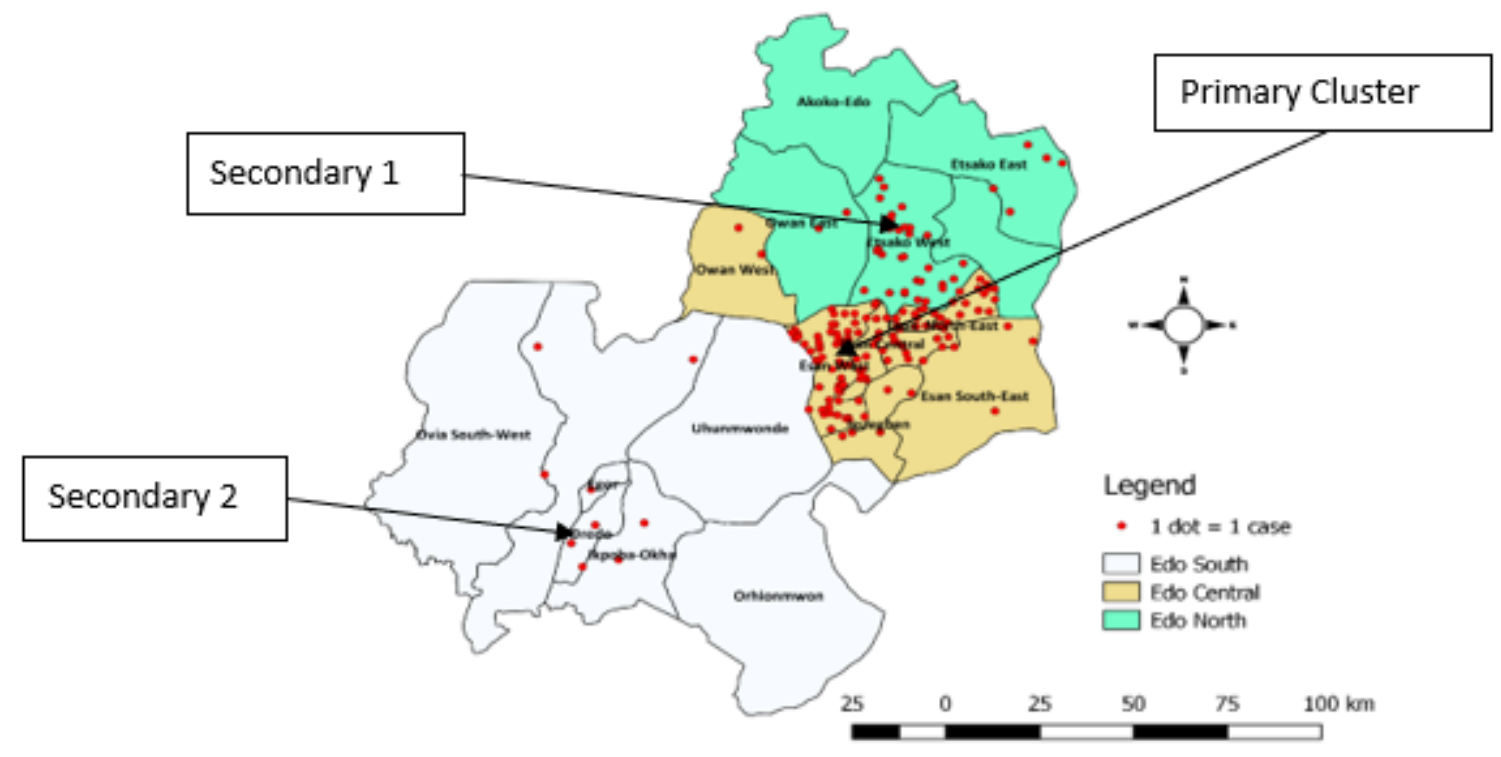

Figure 3

Map showing the spatial distribution of confirmed Lassa fever cases in Edo State, 2008 -2014 


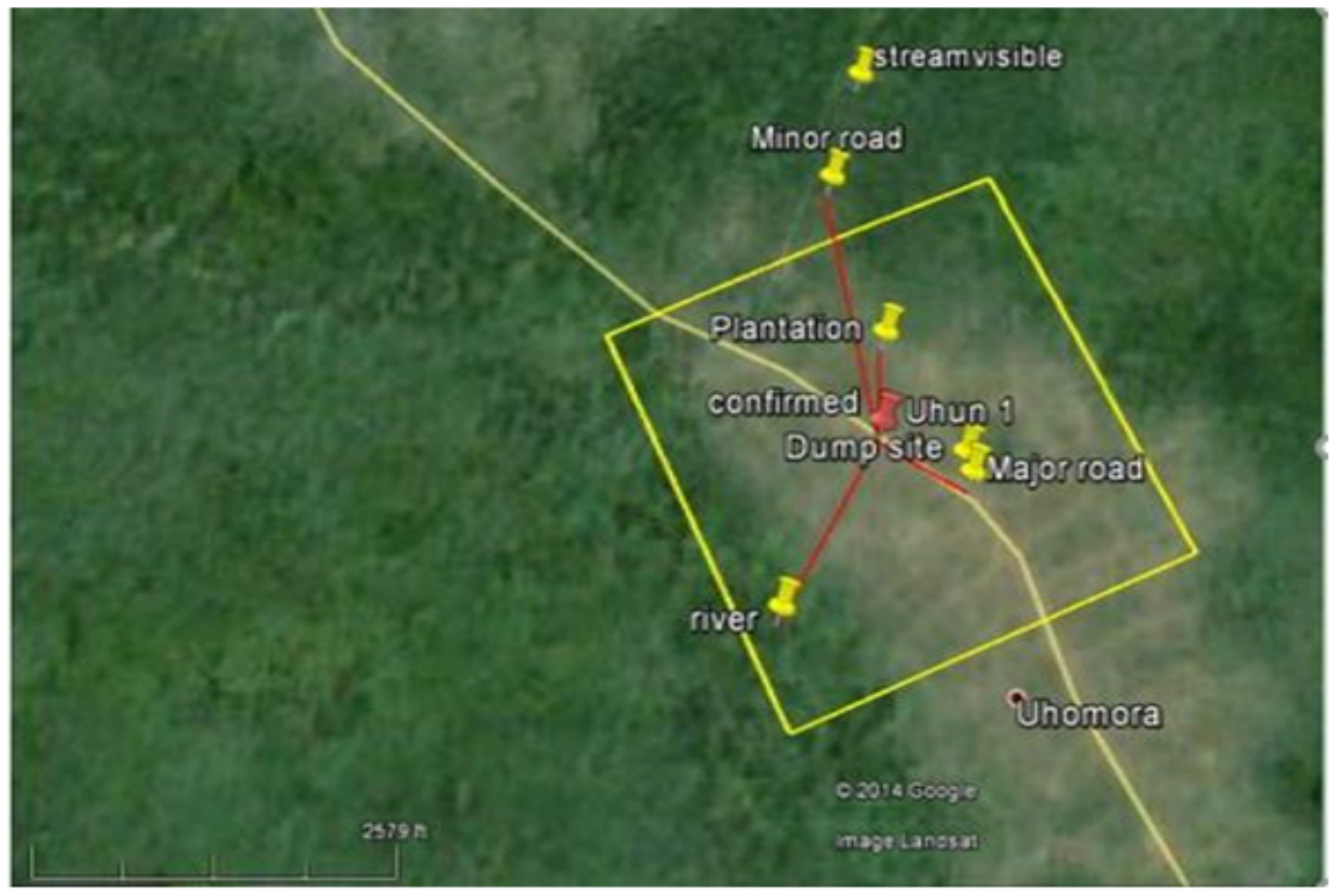

\section{Figure 4}

Enhanced aerial photograph showing multi-environmental variables for confirmed Lassa fever cases in primary clusters, Esan West Local Government Area, Edo State, Nigeria 2008 - 2014

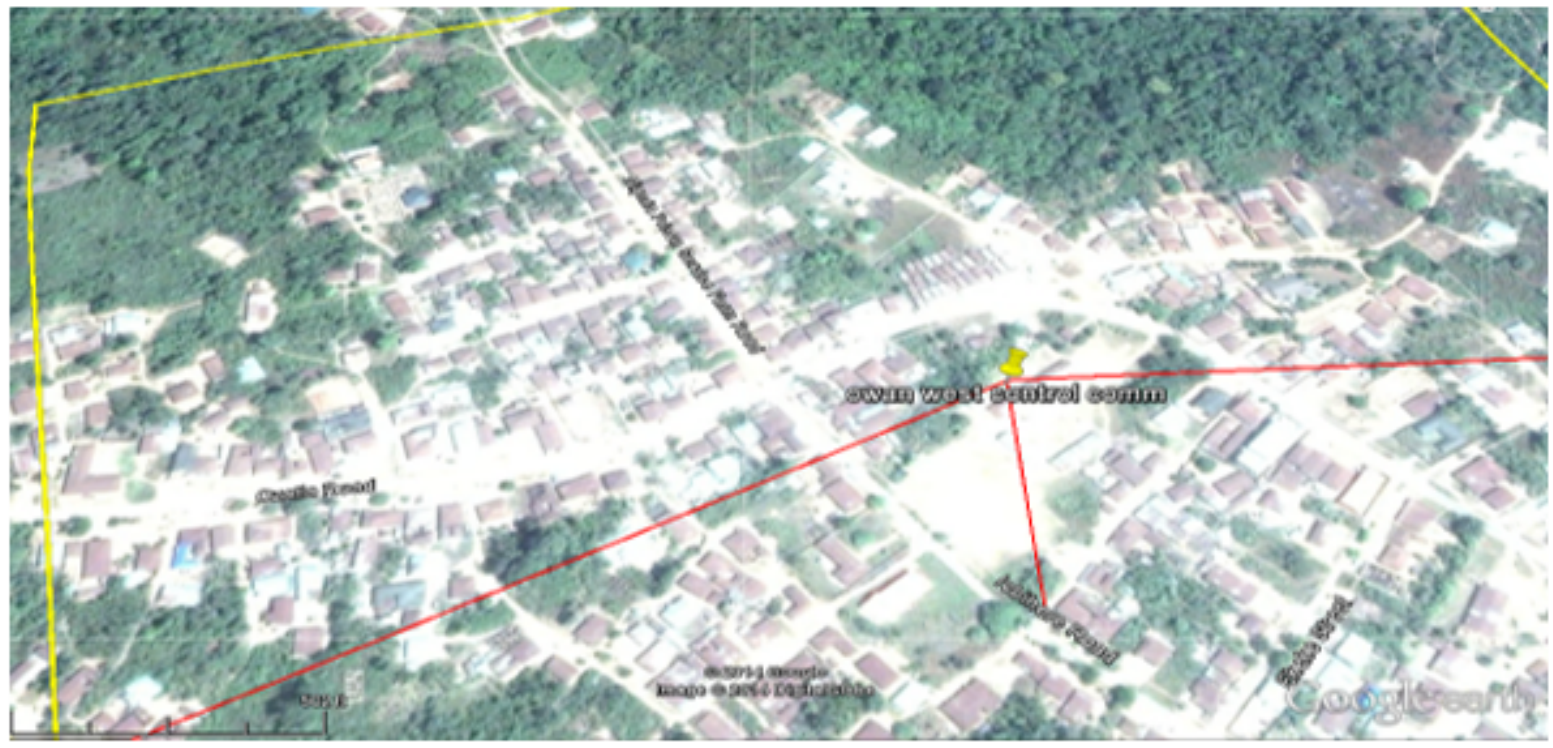

\section{Figure 5}

Enhanced aerial photograph showing environmental factors and house locations in primary cluster of Lassa fever cases in Esan West Local Government Area, Edo State, Nigeria 2008 - 2014 